\title{
A lei da guerra - um tema clássico ${ }^{1}$
}

Rolf Nelson Kuntz - Universidade de São Paulo

Grandes temas do Direito Internacional dos últimos cem anos seriam provavelmente reconhecidos sem muito esforço pelos pioneiros da disciplina, autores dos séculos XVI e XVII. Teriam alguma dificuldade para decifrar decisões da Organização Mundial do Comércio ou para entender o sistema de negociação de créditos de carbono, mas estariam num ambiente familiar quando encontrassem noções como a de não interferência, a de igualdade jurídica dos Estados e a da defesa como única justificativa da guerra.

Esta exposição tratará de três desses pioneiros, o dominicano espanhol Francisco de Vitória, o jesuíta Francisco Suárez, também espanhol, e o advogado holandês Hugo Grotius. O jurista e historiador James Brown Scott refere-se a eles como tendo cumprido três etapas da criação do direito internacional. Vitória foi o primeiro expositor; Suárez, o primeiro filósofo da nova disciplina; Grotius, o que colheu os frutos maduros, deu acabamento à teoria e a popularizou. Brown Scott apresenta esse comentário em seu livro The Catholic Conception of International Law,

${ }^{1}$ Aula inaugural pronunciada na abertura do ano letivo de 2015 no Departamento de Filosofia da USP 
publicado em 1934 e reeditado em 2008 (Cf. Scott, 2008). Num trabalho anterior, de 1928, Brown Scott já havia estudado longamente a obra de Francisco de Vitória, por ele apresentado como o fundador do direito internacional moderno (Cf. Scott, 1928). Pode-se discutir essa distinção, mas não a importância das contribuições daquele dominicano, catedrático de teologia da Universidade de Salamanca a partir de 1526.

\section{Vitória}

A produção política mais importante de Vitória está contida numa série de conferências apresentadas entre 1528 e 1539 e genericamente conhecidas como "relectiones", aulas especiais proferidas em datas festivas, como o dia de Natal. As palestras mais conhecidas tratam do Estado, da lei, do poder da Igreja e da ocupação do recém-descoberto continente americano. As duas dedicadas à questão americana têm como tema central, ou mais ostensivo, as relações dos espanhóis com os índios.

A primeira dessas aulas é conhecida como De indis (ou Sobre os indios). A outra é geralmente mencionada como De iure belli (ou Do direito da guerra). Em ambas, Vitória discute os direitos que os espanhóis alegavam e aqueles que poderiam alegar como fundamento de sua presença na América e do uso da violência contra os povos americanos. Outros autores trataram da violência contra os índios e um deles, o bispo Bartolomé de las Casas, notabilizou-se pela denúncia das atrocidades cometidas pelos espanhóis.

Las Casas e Vitória são lembrados como defensores do que mais tarde seria conhecido como "direitos humanos", mas a contribuição vitoriana mais notável, do ponto de vista jurídico, é a articulação de ideias que durante séculos seriam aceitas como boas diretrizes para uma ordem internacional: 1) o sistema in- 
ternacional é uma sociedade regida por normas aplicáveis igualmente a todos os membros; 2) os Estados componentes dessa comunidade são iguais por direito; 3) a guerra só é justificável como resposta a uma agressão; 4) nenhum Estado tem o direito de intervir nos assuntos de outro para impor sua religião; 5) todo homem, seja qual for sua origem nacional, tem o direito de buscar o contato pacífico e o comércio com os semelhantes de qualquer nacionalidade.

A ideia de que a guerra só é justificável como resposta a uma ofensa, ou, de modo geral, como autodefesa, foi retomada por Grotius, incorporada no chamado sistema de Westfália e afinal incluída na Carta da Organização das Nações Unidas, em seu artigo 51. A aplicabilidade e a interpretação desse artigo foram debatidas intensamente por especialistas nos meses que precederam a invasão do Iraque pelas forças lideradas pelos Estados Unidos, em 2003. Parte do debate foi dedicada à questão da legalidade ou ilegalidade da guerra preventiva - ou preemptiva, entendida como antecipação de um ato do inimigo. Segundo especialistas do Congresso americano, consultados antes do início da guerra, a ação armada seria contrária às normas internacionais, mas esse parecer foi menosprezado pelas autoridades. A doutrina vitoriana permanecia em pé, sustentada pela opinião dos especialistas, mas foi atropelada, juntamente com os dispositivos da ONU, pelas forças enviadas ao Iraque. O governo da Espanha, então liderado pelo primeiro-ministro José Aznar, foi um dos que apoiaram a iniciativa de Washington. Pelo menos um professor espanhol, Francisco J. Oroz, lembrou que a norma contida na Carta da ONU tem uma longa história e divulgou pela Internet uma crítica à decisão de seu governo sob o título Aznar contra Vitória (Cf. Kuntz, 2003). 
A concepção vitoriana do direito internacional é sustentada pela teoria da igualdade dos Estados. Essa é, segundo Brown Scott, a pedra fundamental do sistema. A igualdade vale não só para os Estados da cristandade, mas também para os governados por pagãos e, portanto, para as sociedades americanas, classificadas por Vitória como entidades políticas comparáveis às da Europa. Quanto a este ponto, o pensamento vitoriano retoma um ponto de vista já expresso dois séculos antes por outros pensadores cristãos, incluído Ockham. A base dessa opinião é a teoria aristotélica da naturalidade da polis e, portanto, do governo. A tese da naturalidade aplica-se tanto aos Estados cristãos como aos demais.

Isto nos leva à teoria vitoriana do Estado e do poder, exposta em 1528 na Relectio de Potestate Civili (ou Lição sobre o Poder Civil), a primeira das treze conferências conhecidas como relectiones. Vitória introduz a lição anunciando que falará como teólogo, pois, segundo ele, é imenso o campo de problemas que a teologia recobre. Ele não discorrerá, portanto, apenas como jurista, conselheiro de príncipes ou filósofo ocupado com os fatos do mundo natural, mas como estudioso que se ocupa de todos esses temas e também das coisas de Deus. A mesma reivindicação valerá para as demais lições sobre temas políticos e jurídicos, nos anos 30. Suárez e Bellarmino também são teólogos e não deixam de se ocupar da política - e da lei, extensamente, no caso do primeiro.

Vitória propõe, no começo dessa lição, um tema extraído de uma Epistola de São Paulo aos romanos: "Não há poder que não emane de Deus". O tratamento do assunto é escolástico na forma - questões, respostas, objeções e um balanço final de cada série de argumentos — e aristotélico na inspiração. Mas o 
viés escolástico é aggiornato, segundo a agenda política do momento, e o aristotelismo é transplantado para um cenário muito diferente da cidade-Estado grega, assim como já fora nos trabalhos de São Tomás. Interessa a Vitória o Estado moderno. As categorias da política são as adequadas a esse Estado, incluída a noção de um príncipe legibus solutus.

A maior parte da Europa é dominada pelas grandes monarquias consolidadas e uma das mais poderosas, nesse momento, é a espanhola. O império, um anacronismo, só se distingue nominalmente de qualquer outra potência. A reforma protestante cindiu a cristandade e a Igreja Romana tenta reorganizar suas forças para responder ao desafio das novas formas de cristianismo.

Suárez e Bellarmino, décadas depois de apresentadas as principais contribuições de Vitória, terão importância na formulação das teses católicas a respeito de como a Igreja Romana deve relacionar-se com os príncipes protestantes. Os primeiros reformadores, com a doutrina da graça e da impossibilidade da justiça inerente às ações humanas, tendiam a rejeitar o fundamento natural da sociedade política e difundir a doutrina de que só o príncipe devoto tem o poder de legislar (Cf. Skinner, 1996, pp. 418-421).

O quadro se completa com os problemas criados pela chegada dos europeus ao continente americano. Esses problemas incluem as relações com os habitantes da América e a revisão do sistema de normas até então destinado a disciplinar a convivência dos povos.

Nesse momento, portanto, tem novo peso a reafirmação do caráter natural do Estado, isto é, a caracterização da pólis como exigência da natureza humana. Não há novidade essencial na 
descrição da res publica, ou civitas, como a condição indispensável à segurança e à realização das potencialidades do homem. O Estado é novamente caracterizado, numa fórmula fiel à tradição aristotélica e tomista, como a sociedade perfeita, autossuficiente. Mas a antiga noção de autarquia perde importância. O conceito de soberania, ainda sem explicitação completa, é mais adequado que o de autarquia para descrever a posição de cada Estado diante dos demais. Quando Vitória apresenta a primeira relectio, os componentes políticos e jurídicos da ideia de poder soberano estão maduros e em breve serão enunciados de forma completa.

A primeira tese importante apresentada na primeira lição conduz à ideia de naturalidade do poder político. Se a sociedade política é natural, por derivar de uma exigência da condição humana, o poder político também o é, por ser necessário ao governo dessa comunidade. Sociedade e governo são, portanto, fundados na lei natural e, como essa lei provém de Deus, é Ele a causa eficiente do poder. A comunidade, ou República, é apenas sua causa material. A comunidade assume a tarefa de constituir um governo e orientar seus poderes para o bem comum. Esse poder é investido originalmente na comunidade, pois, na ausência de uma determinação divina ou de uma escolha dos homens, não se pode supor que alguns indivíduos tenham naturalmente o direito de comando sobre os outros (Vitória, 1985, p. 7). Esta concepção da igualdade natural dos indivíduos seria uma das teses mais importantes do pensamento neotomista. Seria afirmada tanto por dominicanos, como Vitória e De Soto, quanto por jesuítas, como Suárez e Bellarmino. Ao escrever o Patriarca, em defesa da ideia da origem divina do poder dos monarcas, Robert Filmer se dedica, em primeiro lugar, a uma tentativa de refutação dos neoescolásticos, defensores da ideia da igualdade 
natural dos indivíduos. Em sua contestação do livro de Filmer, inicialmente com o Primeiro tratado sobre o governo civil, Locke sustenta a tese de igualdade original de direitos enunciada por aqueles teólogos. Boa parte do Segundo tratado é dedicada à mesma tarefa.

Nesse ponto ocorre um dos movimentos mais difíceis e menos claros, à primeira vista, da exposição vitoriana. É a afirmação de que o poder do rei seria derivado não da República, mas imediatamente de Deus. O Estado ou comunidade política, segundo Vitória, constitui o rei, e transfere-lhe sua autoridade, mas não é a fonte de seu poder. O próprio texto da lição sobre o poder civil não estabelece claramente a distinção entre potestas e auctoritas. Essa distinção é estabelecida noutros textos, como o comentário sobre a Suma teológica e a primeira lição Sobre o poder da Igreja. Em sentido político, potestas é a capacidade de agir, e esta provém de Deus tanto para o Estado quanto para o rei. Mas é uma capacidade vinculada a uma auctoritas. A explicação de Anthony Pagden, autor do texto introdutório às traduções inglesas publicadas pela Cambridge, parece satisfatória: como o poder real proveniente de Deus não pode ser exercido no vazio, "os reis devem receber sua autoridade ou poder executivo da comunidade". O mesmo intérprete observa que, nas lições Sobre as leis dietárias (ou de Autorrestrição), Vitória afirma que o poder, agora entendido, como autoridade, provém do povo (Cf. Pagden in Vitória, 1991, p. XIX).

Pagden, no entanto, vincula a afirmação da origem divina do poder à tentativa de Vitória de valorizar a monarquia como a melhor forma de governo. Essa interpretação é discutível. Embora seja explícita a preferência de Vitória pela monarquia, é preciso não esquecer que a discussão sobre o poder real é apenas 
um passo das considerações sobre o estabelecimento do governo, isto é, dos poderes necessários ao Estado para administrar e defender a República. Embora a comunidade, por lei divina, tenha poder sobre seus membros individuais, é impossível que esse poder seja administrado por ela mesma, isto é, pela multidão.

Portanto, é necessário que o governo e a administração de seus assuntos sejam confiados a alguns homens que assumem as responsabilidades da comunidade e cuidam do bem comum. É irrelevante que se trate de alguns homens, como na oligarquia, ou de um único homem, como na monarquia: em qualquer caso, se o poder da comunidade não for tirânico mas justo, então o poder de um monarca será justo também, pois não será senão o poder da comunidade (República) administrado por meio do príncipe (Vitória, 1991, p. 14).

Tudo isso porque a República, como tal, "não pode legislar, propor políticas, julgar disputas, punir transgressores ou, em geral, impor suas leis aos indivíduos, e assim, necessariamente, deve confiar todos esses assuntos a um homem". Note-se que o argumento vale, de fato, para um homem ou para qualquer número que se destaque da própria comunidade política. Argumento semelhante é apresentado por Suárez em seu Tratado sobre a lei e o Deus legislador (De Legibus ac Deo Legislatore).

As faculdades necessárias ao cumprimento dessas funções legislar, julgar, punir etc. — são aquelas que a comunidade não pode, isto é, não tem o direito de retirar do príncipe. Se o fizer, a República ficará sem meios para agir, administrar e se defender. Esses poderes provêm de Deus, segundo Vitória, porque a 
instituição de um príncipe, ou de quem quer que receba o papel de agir em nome da República, não resulta de uma escolha entre alternativas equivalentes. O governo é uma necessidade natural, não um produto arbitrário da vontade humana. Também por isso - porque esse poder vem de Deus, não de um ato moralmente indiferente -, as leis positivas obrigam em consciência, isto é, seu descumprimento não é apenas um delito, mas também um pecado. Dessas leis não se isenta nem o detentor dos poderes públicos, embora ele tenha o poder de modificá-las e de as revogar. Esse príncipe, portanto, é legibus solutus apenas no sentido de que lhe cabe com exclusividade o poder de legislar, de revogar e de mudar a lei. Esse poder é incontrastável e só por meio dele uma norma costumeira se torna vinculante, como afirma Vitória num comentário sobre a Suma teológica. Em outras palavras, só a autoridade política é fonte da lei civil, por maior que seja a importância social do costume. Essa tese reaparece no capítulo XXVI do Leviatãa, dedicado a uma ampla exposição sobre a lei civil.

Vitória pode citar o nome e as teorias de Aristóteles muitas vezes, mas não há como transplantar a polis grega para este universo, nem como retomar a noção da autarquia para caracterizar a independência do Estado. As noções fundamentais, agora, são de outra ordem. Ressaltam-se a jurisdição exclusiva do poder político sobre a República e a figura do soberano como fonte da lei e da justiça. Em Vitória, como observa Pierre Mesnard, a doutrina da soberania está muito próxima da formulação que será apresentada por Bodin, na segunda metade do mesmo século, em seus Seis Livros da República. Em seu monumental volume sobre L'Essor de la philosophie politique au XVIe siècle, Mesnard apresenta Bodin no capítulo seguinte ao dedicado a 
Vitória. Não deve ser uma simples coincidência.

É dessa concepção de soberania como necessidade natural da República, e, portanto, como expressão da lei natural e da vontade de seu autor, Deus, que se extrai a noção de que os príncipes infiéis são tão legítimos quanto os cristãos, com os mesmos direitos e a mesma superioridade em relação às respectivas comunidades políticas. É nesta concepção de naturalidade da sociedade política e do governo que se funda, também, a ideia da igualdade jurídica entre os Estados, um dos pilares do Direito Internacional moderno. Mas esses príncipes, cristãos ou pagãos, têm agora uma característica nunca antes enunciada com tanta clareza: um tipo de poder que o pensamento político e a teoria jurídica apenas começaram a explorar e que ainda não está plenamente explicitado. Esse atributo, o poder soberano, é também um elemento novo na caracterização do sistema internacional.

É necessário, aqui, darmos um passo atrás para reconsiderar, por um momento, a força vinculante da lei. O príncipe é livre para legislar desta ou daquela maneira, mas, uma vez definida a lei, deve a ela se sujeitar, da mesma forma como se é livre para entrar num pacto mas não para violar a palavra empenhada. $\mathrm{O}$ legislador, em Vitória, está acima da comunidade pelos poderes que detém, mas é parte da comunidade como súdito da lei.

Ao tratar da necessária sujeição do príncipe às leis que ele mesmo formula, Vitória introduz, de forma um tanto inesperada, o seguinte corolário: "Que a lei das nações (ius gentium) não tem meramente a força de pactos ou acordos entre os homens, mas tem a validade de uma norma positiva (lex)". E acrescenta: "O Mundo todo (totus orbis), que em certo sentido é uma República, tem o poder de promulgar leis justas e conve- 
nientes para todos os homens e estas compõem a lei das nações". E mais à frente: "Nenhum reino tem o direito de ignorar esta lei das nações, porque tem a sanção de todo o mundo" (Vitória, 1985, p. 19).

Mas a surpresa do leitor logo desaparece, quando se retomam dois pontos tratados em passagens anteriores da lição sobre o poder civil. O primeiro é a responsabilidade da República pelos atos do príncipe que ela constitui. Se esse príncipe comete uma injustiça, toda a comunidade é responsável e merece igualmente a punição que esse ato possa ocasionar. Mas a ideia de punição pressupõe normas que permitam distinguir o justo e o injusto. A noção mais simples é a do direito de autoproteção, que se desdobra nos direitos de compensação dos danos sofridos e, enfim, de punição do crime. A República é titular do direito de autodefesa não só contra os crimes dos próprios súditos, mas também contra as ofensas cometidas por forças exteriores.

Essas noções são derivadas em primeiro lugar de uma concepção forte da lei natural. Essa lei natural estabelece obrigações em relação a Deus, que é o seu autor, aos demais homens e também aos Estados. Estabelece também os direitos de autodefesa e de retaliação, ou punição, cujo exercício o príncipe deve sempre ponderar relativamente às conveniências do próprio Estado, da cristandade e também da ordem geral do mundo.

Ao definir os poderes, direitos e obrigações do príncipe em relação a cada República e ao sistema internacional, Vitória se move num território muito distante do pensamento antigo e mesmo do pensamento político medieval, embora utilize, com frequência, citações de autores da Antiguidade e da Idade Média.

A lição sobre o poder civil trata do Estado, portanto, sob 
uma dupla perspectiva, examinando ao mesmo tempo sua ordenação interna e sua inserção na ordem mundial. Em termos modernos, podemos dizer que a República é examinada, nessa lição vitoriana, sob dois pontos de vista complementares, o do Direito Constitucional e o do Direito Internacional Público.

A discussão sobre o Direito Internacional é aprofundada e ampliada nas duas lições sobre os índios. A primeira, intitulada Sobre os indios recentemente descobertos, é exposta em duas partes. A inicial é dedicada a um exame crítico das alegações habitualmente usadas para justificar a pretensão de domínio dos europeus sobre os povos americanos e sobre as riquezas do Novo Mundo. Na sequência, Vitória expõe os "títulos legítimos" que os espanhóis poderiam alegar como justificativas de suas ações contra os índios.

A parte crítica não envolve dificuldades. A maior parte dos argumentos de Vitória é baseada na lição sobre o poder civil. Os argumentos criticados são os seguintes: o domínio universal do imperador; o poder do papa sobre as coisas temporais; o direito de descobrimento; a resistência dos índios ao cristianismo; os pecados dos índios; a sujeição voluntária dos índios aos espanhóis; uma doação especial de Deus.

Vitória responde a todas essas alegações com fatos facilmente reconhecíveis, e com argumentos. Não há indício de que o imperador tenha domínio universal por direito de natureza, por direito divino ou por direito humano. Uma vez aceita a teoria da liberdade natural dos homens, já discutida na lição sobre o poder civil, não haveria como admitir, exceto por efeito de uma decisão humana, da qual não há notícia, a existência de um império universal. Em relação ao segundo ponto, Vitória reproduz a argumentação exposta nas lições sobre o poder da Igreja. Um 
dos argumentos centrais é que o poder temporal do papa é limitado pelas necessidades de sua função espiritual. Essa função não inclui o direito de redistribuir os bens alheios. A ideia de um direito vinculado ao descobrimento é rejeitada sem nenhuma dificuldade. Como afirmar que a América foi "descoberta", se os índios lá estavam organizados socialmente e desfrutando da posse pacífica de suas terras e de seus outros bens? Este mesmo argumento seria usado, no começo do século seguinte, por Hugo Grotius, para contestar as pretensões espanholas e portuguesas de exploração exclusiva do comércio com as Índias Orientais.

Os pontos fundamentais do raciocínio de Vitória são as noções relativas à igualdade dos Estados e à legitimidade dos príncipes pagãos, como os índios, ou mesmo pecadores. O dominicano não manifesta a menor dúvida quanto ao fato de que as sociedades indígenas, pelo menos aquelas organizadas em torno de uma chefia, tenham a mesma natureza dos Estados a respeito dos quais ele teorizou na lição sobre o poder civil.

O passo seguinte é apontar as justificativas possíveis das pretensões dos espanhóis em relação à América. São enumerados sete títulos legítimos: 1) o direito de sociedade e comunicação, desde que exercido sem dano para com os índios; 2) o direito de propagação pacífica do cristianismo; 3) a defesa dos direitos dos índios de se tornarem ou não cristãos; 4) a outorga de um príncipe cristão aos que se tenham convertido; 5) a proteção dos índios (ou de quaisquer povos) contra a tirania e as práticas desumanas que sejam impostas por seus príncipes; 6) uma verdadeira sujeição dos índios a um novo poder, se for decidida livremente; 7) o direito de aliança, se uma república indígena pedir ajuda contra uma sociedade agressora.

Os argumentos de Vitória são redutíveis, nesta parte, a quatro 
ideias básicas: 1) o direito de reação a uma injúria (no caso de violação do direito de sociedade e de comunicação, ou no caso de violência contra os pregadores, por exemplo); 2) o direito de agir em defesa dos oprimidos (equivalente, em termos modernos, ao direito de intervenção humanitária); 3) o direito de aliança e 4) o direito de uma República de transferir a autoridade de um príncipe para outro (Ibid., pp. 65-70).

A segunda lição sobre os índios, mais conhecida como lição Sobre o direito de guerra, aprofunda e sistematiza noções introduzidas na primeira e também na exposição Sobre o poder civil.

O primeiro passo é examinar se a guerra é lícita para os cristãos. É um movimento previsível, que Grotius deveria repetir quase um século depois na abertura de seu livro mais importante, $O$ direito da guerra e da paz. Vitória examina os textos sagrados, que mostram a licitude da guerra tanto no Velho quanto no Novo Testamento, e também a lei natural. Esta permite essencialmente a guerra defensiva, mas também a ofensiva é lícita, como desdobramento da outra, porque é preciso, para tornar eficaz a defesa, impor sofrimento a quem cometeu ou tentou cometer a injúria. É função da guerra não só repelir a ofensa, mas também proporcionar a reparação dos danos e, enfim, desencorajar os atos de agressão pelo castigo dos culpados.

É neste ponto (e ainda no começo da lição) que Vitória introduz o elemento mais importante na arquitetura de sua teoria das relações internacionais. A guerra justifica-se não apenas para a defesa da República, mas também para benefício de todo o mundo. É o sétimo argumento enumerado. "De nenhum modo o orbe poderia permanecer num estado feliz e, além disso, chegaríamos ao pior estado de coisas, se os tiranos, os assaltantes 
e os ladrões pudessem impunemente fazer injúrias e oprimir os bons e inocentes, e não fosse lícito a esses repelir suas agressões e castigá-los" (Ibid., p. 78).

Essa referência ao Mundo (totus orbis) não é retórica. É esse conceito que torna comparáveis a lei natural, a lei das nações (ius gentium) e a lei positiva dos Estados, permitindo aplicar ao conjunto das relações internacionais a noção de uma ordem coletiva, de uma ordem pública na mais ampla dimensão. A lei natural, embora criada por Deus, não regula somente as relações entre os indivíduos e a divindade, ela comanda também a interação dos indivíduos e lhes impõe a constituição das sociedades políticas. Num plano mais amplo, é um dos fatores de ordenação do sistema interestatal. O outro é a lei das nações, que resulta do acordo geral ou da maior parte dos Estados. Esta lei, explica Vitória num comentário sobre o pensamento de São Tomás, deve ser situada "mais sob a lei positiva do que sob a lei natural" (Ibid., p. 80).

O orbe, na doutrina vitoriana, não é apenas um grande pano de fundo no teatro da vida internacional. Vitória utiliza a ideia de comunidade internacional no sentido mais forte. Esse totus orbis tem os atributos de uma sociedade política. Se a República pode punir os cidadãos nocivos, afirma o dominicano, "não há dúvida de que o orbe poderá também fazê-lo com os homens perniciosos e malvados, e isto será executado por intermédio dos príncipes" (Ibid.).

A grande diferença entre a República soberana e a República universal consiste, portanto, em que a primeira age por meio de um governo constituído pelos cidadãos, enquanto a segunda opera de forma descentralizada, por meio dos príncipes. Cabe a estes, por meio da guerra justa, cumprir a função de reprimir os 
maus, de julgá-los e de puni-los. Referências ao papel judicial do príncipe vencedor da guerra justa aparecem várias vezes na lição Sobre o direito de guerra. Se um juiz superior pode punir o autor de uma ofensa, privando-o de uma cidade ou de um castelo, "também o príncipe ofendido poderá fazer o mesmo", afirma Vitória, "já que por direito de guerra se converteu em juiz" (Ibid.). A esse príncipe o dominicano recomenda as mesmas virtudes que se esperam de quem aplica a lei no interior de uma República. No final da lição, aparece a seguinte regra:

Obtida a vitória e terminada a guerra, convém usar do triunfo com moderação e modéstia cristã, e que o vencedor se considere como juiz entre duas Repúblicas, uma ofendida e outra que perpetrou a injúria, para que, desta maneira, profira sua sentença não como acusador, mas como juiz, para satisfazer a nação ofendida (Ibid).

A mesma noção de uma sociedade internacional ordenada por leis eficazes voltaria a aparecer no pensamento de Grócio. Richard Tuck observa que a teoria grociana é essencialmente a mesma que Locke apresenta no Segundo tratado, ao afirmar que os indivíduos, no estado de natureza, exercem jurisdição recíproca e são instrumentos, portanto, de aplicação da lei natural. Tuck lembra ainda, com certo humor, que Locke expõe essa ideia como algo que muitos poderiam estranhar (Cf. Tuck, 1982, cap. 8). Mas a noção de que a lei natural e o direito das gentes são eficazes e aplicáveis por meio de agentes descentralizados não é de origem grociana, pois já se encontra claramente desenvolvida na obra de Vitória.

É essa concepção que ilumina e torna amplamente inteligíveis 
todos os detalhes das leis que tratam da questão de quando e por que se pode guerrear, e do que é lícito fazer na guerra. Já está suficientemente desenvolvida, nesta obra, a noção de um sistema legal descentralizado e sem tribunais e instituições especializadas, mas, ainda assim, dotado de uma eficácia possível. Com a obra de Vitória, a concepção de uma ordem jurídica internacional torna-se mais clara, mais articulada teoricamente e mais plausível. Não seria um despropósito apontar essa obra como ponto inicial de uma das duas principais vertentes da teoria das relações internacionais. Uma delas admite, a outra rejeita a ideia de uma legalidade internacional em sentido estrito. A primeira é às vezes designada como tradição grociana, mas sua origem é anterior a Grotius. A outra é a tradição hobbesiana.

\section{Suárez}

Outro autor indicado por James Brown Scott como parte do trio fundador é o jesuíta Francisco Suárez, formado em Salamanca, mas que não pode ser classificado como discípulo de Vitória. Sua obra principal é um tratado monumental Sobre as leis e sobre Deus legislador. É obra de teólogo, assim como as lições vitorianas, mas o resultado principal é uma poderosa contribuição à política e à teoria do direito internacional.

Suárez parte da análise tomista da noção de lei e a desenvolve longamente nos dois primeiros livros de seu De Legibus ac Deo Legislatore, publicado em Coimbra em 1612. Como tarefa preliminar, no entanto, ele trata de esclarecer as diferenças entre lex e jus, um cuidado que aparece também no começo da principal obra de Grócio e, mais tarde, no início do capítulo XIV do Leviatã. A distinção, tão cara à tradição anglomericana, tem, como se vê, raízes continentais, afinal esquecidas no próprio continente. 
Sua noção de lex acaba sendo diferente, afinal, daquela proposta por São Tomás: "uma regra ou medida de acordo com a qual alguém é induzido a agir ou a abster-se da ação" (Suárez, 1967, vol. I, p. 11). Suárez depura essa definição, que parece incluir também os conselhos na ideia de regra ou medida. Sua abordagem realça três componentes da lei, indicados no livro terceiro: a força vinculante em relação à consciência, a força coercitiva, que envolve a punição, e a força pela qual uma forma definida é imposta aos contratos e a outros atos ditos legais como condição de sua validade. (Se alguém estiver pensando na distinção entre norma primária e norma secundária, confesso que também estou).

Quanto ao conceito de jus, ele o define como "certa faculdade moral de cada homem relativamente à sua propriedade ou quanto àquilo que lhe é devido" (Ibid.). Lei e direito podem coincidir em vários pontos, mas, segundo Suárez, há algo, no direito, que não se enquadra no universo do comando e que independe da existência da lex. Ele usa, no entanto, o termo jus, como se faz correntemente no seu tempo, para designar tanto a lei quanto o direito, mas previne o leitor para estar atento ao sentido adequado a cada passagem.

Como Vitória, Suárez desenvolve uma teoria do Estado e do poder civil e discute as limitações do poder estatal. Ele enfrenta este problema não apenas como teórico preocupado com questões abstratas e gerais, mas também como defensor de sua Igreja. Envolve-se no debate sobre a expulsão de religiosos católicos da Inglaterra, em 1604, e sobre o juramento de fidelidade imposto aos súditos por Jaime I. Esse juramento inclui, entre outros pontos, o compromisso de lealdade ao rei mesmo no caso de sua excomunhão. Nessa discussão, Suárez desenvolve uma primeira 
tese sobre a limitação do poder civil, construindo uma doutrina do poder indireto da Igreja, exercido em princípio por meio da potestas directiva, mas, em caso extremo, da vis coactiva, até o ponto, se necessário, da deposição do príncipe herético, imoral ou ameaçador da Igreja.

Uma segunda forma de limitação do poder estatal é dada pelas exigências da vida internacional. Sem que isso comprometa os direitos de soberania, cabe aos príncipes observar certas normas adequadas à paz ou, quando houver ameaça ao Estado, à condução da guerra justa. Embora não exista, no plano internacional, um poder comum semelhante ao encontrado nas sociedades políticas organizadas, é possível falar de obrigações e direitos nas relações interestatais (Ibid., Vol. II, p. 203).

Essas normas são definidas, na maior parte, pelo direito das nações, ou jus gentium. A lei das nações e a de natureza coincidem em vários pontos e são universalmente válidas, diferenciandose, quanto a este ponto, da lei civil, própria de cada Estado. Mas a lei natural - e aqui eu me valho da excelente síntese apresentada por Pierre Mesnard (Cf. Mesnard, 1936) - ordena ou proíbe o que é bom ou mau em si, enquanto a lei das nações acolhe as normas acordadas pelos atores da vida internacional. Essas normas incluem tanto as condições de coexistência pacífica - como as convenções comerciais e diplomáticas — quanto as disciplinas aplicáveis à guerra. Indispensável em certos momentos e até obrigatória para os príncipes, a guerra é compatível com o regime da lei e dos direitos.

\section{Grotius}

Grotius pode ter colhido os frutos plantados e amadurecidos por Vitória e Suárez, como afirma James Brown Scott, e não é difícil argumentar a favor dessa tese. O jurista holandês de fato 
reúne, como poucos, uma preciosa experiência no tratamento de questões concretas do direito internacional - advogou para a Companhia das Índias - e uma rara competência para organizar teoricamente o material estudado. Seu primeiro trabalho importante no campo do direito internacional só foi conhecido completamente no século XIX, quando foram descobertos os manuscritos de um grande livro intitulado De jure Predae (Sobre o direito de presa). Até essa descoberta só se conhecia desse livro o capítulo XII, Mare Liberum, considerado um livro independente. De Iure Predae nasceu de um esforço para justificar a captura de um navio português, no Oriente, por um comandante a serviço da Companhia. O objetivo do trabalho era convencer parte dos acionistas a aceitar os lucros derivados dessa captura. A rejeição era de natureza religiosa. A obra saiu muito mais ampla do que deveria ser um arrazoado a favor do ataque ao barco português e por mais de duzentos anos só um de seus capítulos foi conhecido. Mas o livro, concluído na primeira década do século XVII, foi um importante exercício para a obra que permitiria a Grotius ocupar um dos postos mais altos na história do pensamento jurídico moderno, o tratado sobre $O$ direito $d a$ guerra e da paz, publicado em 1625.

Há uma excelente razão para o direito da guerra aparecer na primeira parte do título. É esse, de fato, o grande tema do livro - uma derivação do trabalho profissional de Grotius. Na época, sua referência era o estado de guerra entre a Holanda e a Espanha. A hostilidade envolvia indiretamente Portugal, controlado pela coroa espanhola entre 1580 e 1640. A reflexão sobre o direito da paz poderia trazer alguma dificuldade, como hoje acontece com a questão das normas comerciais, por exemplo. Mas o problema da guerra era e continua sendo muito mais complexo, 
em seus aspectos legais e morais, pois envolve a violação de padrões normalmente apontados como os mais apropriados à vida social.

Desde o início, O direito da guerra e da paz é um exercício de virtuosismo. É preciso, em primeiro lugar, mostrar que o livro não é um contrassenso. Grotius não se permite simplesmente desconhecer os autores que negam o direito ou reduzem as noções do justo e do injusto a meras convenções ou as descrevem como distinções impostas pelo mais forte. O desafio é particularmente complexo no caso da guerra. De fato, é um desafio duplo. Trata-se de mostrar não só que tem sentido falar no direito, em situações de guerra, mas também que a própria guerra pode ser justificada pelo direito.

Grotius toma Carnéades como opositor exemplar. Segundo ele, não há direito natural; homens e animais são levados por sua natureza a cuidar da própria utilidade e, se houvesse justiça, seria uma loucura, pois levaria cada indivíduo a sobrepor interesses dos outros aos próprios. Não são teses desprezíveis.

Como resposta, Grotius afirma a sociabilidade humana. O homem tem uma tendência natural para a vida coletiva, porque não pode subsistir fora da sociedade, e para nela viver dispõe da linguagem e de uma faculdade exclusiva, a de conhecer princípios gerais e de segui-los em suas ações.

Dessas características decorrem as leis e os direitos naturais: são regras e faculdades necessárias à vida social. Concordam com a lei os comportamentos favoráveis à coexistência dos homens. Contrariam a regra as ações nocivas à vida social. Para conhecer a lei, o homem dispõe de um julgamento capaz de apreciar as coisas desejáveis ou nocivas, presentes e futuras, os meios de obtê-las e a sua hierarquia. A razão é suficiente, portanto, 
para indicar as condições essenciais à cooperação e à paz entre os homens, como o respeito aos bens alheios, o cumprimento das promessas, a reparação dos danos e a distribuição dos castigos merecidos. Fixado este ponto, Grotius tem o necessário para fixar sua alavanca e pôr em movimento o restante da argumentação.

A lei natural decorre das características da natureza humana. A lei e suas consequências não poderiam ser diferentes, portanto, mesmo se negássemos a existência de Deus ou o seu interesse pelos assuntos humanos. Essa negação, admite Grócio, seria "um grande crime". Além disso, há bons fundamentos para a crença em Deus. Mas a conclusão é incontornável: se a lei natural e suas características decorrem necessariamente dos atributos da espécie humana, podemos conhecer essa realidade sem levar em conta a ideia de seu criador. Há nesse argumento, é claro, uma importante hipótese embutida: a natureza poderia ser a mesma, se o Criador não existisse (Grotius, 2004, v. 1, p. 40).

Ao explicitar esse ponto, sustentam alguns intérpretes, Grotius dá um passo além da tradição, liberando a ideia de lei natural de todo compromisso com a teologia. É uma avaliação discutível. A apresentação da hipótese ímpia pode ser uma novidade, mas não a ideia de uma lei acessível à razão ou de uma regra inscrita nos corações dos homens. Essas noções estão bem estabelecidas não só na tradição estoica, dominante no pensamento de Grotius, mas também na herança aristotélica presente em São Tomás, noutros grandes medievais e nos principais neoescolásticos.

Assim como a lei natural decorre da sociabilidade humana, a lei civil é uma exigência das normas identificadas pela razão. Não haveria meio "mais conforme à natureza" de obrigar os ho- 
mens a cumprir seus compromissos. Nesse sentido, portanto, e não no identificado por filósofos como Carnéades, o direito é ligado à utilidade: não podendo viver isoladamente, os homens devem se associar, submeter-se à autoridade e criar os meios necessários à manutenção da ordem social.

Mas a sociabilidade não se esgota nos limites de cada Estado. Também os Estados dependem uns dos outros e desse fato decorre a criação de regras para sua coexistência, conhecidas como direito das gentes ou das nações. Mas não só essas normas regulam a relação entre os povos. Elas não seriam suficientes, pois só obrigam os participantes de acordos e tratados internacionais. A lei das nações não revoga nem torna dispensável o ordenamento comum a toda a espécie humana, a lei natural, fonte primária de todos os deveres e proibições tanto na paz quanto na guerra.

Grotius dedica boa parte do livro I ao esclarecimento da noção de direito. Na tradição da escrita latina, o termo ius aparece com significados diversos. Três sentidos são discriminados. Em primeiro lugar, ius designa o justo. É a função substantiva, típica da antiguidade, como apontaria Michel Villey. Em segundo, serve para indicar uma liberdade, faculdade ou aptidão. Corresponde à noção moderna de direito subjetivo. Em terceiro lugar, é sinônimo de lex, lei, regra, comando. A lex pode ser natural ou voluntária. A voluntária é divina ou humana, e esta se divide em infraestatal, estatal e supraestatal (ou lei das nações). Essa classificação é essencial à clareza da exposição. Em Hobbes, a discriminação entre ius e lex, apresentada no começo do capítulo XIV do Leviatã, é um passo fundamental na construção da teoria legal e política. A distinção hobbesiana tornou-se parte da tradição cultural dos povos de língua inglesa e não é uma simples firula vocabular. Essa tradição é com frequência atropelada 
em traduções de obras em inglês para os idiomas continentais.

É preciso, em seguida, verificar se as noções de lei e direito são aplicáveis à guerra. A resposta indicada nos Prolegômenos é desenvolvida nos livros I e II. No primeiro, trata-se de mostrar que o recurso à violência é compatível com a lei natural e com a lei divina. Grotius recorre ao testemunho dos antigos, a exemplos históricos e a citações das Escrituras e de autoridades cristãs. Ele não pode fugir da argumentação teológica, incontornável na maior parte dos debates políticos de seu tempo. Mas a argumentação decisiva é a referência aos primeiros princípios da natureza e aos ensinamentos da reta razão (recta ratio). Uns e outros autorizam o recurso à força para a defesa do corpo, da vida e dos meios necessários à existência, quando esses direitos são violados por outros agentes.

O uso da violência pode ser um meio de garantir os objetivos da vida social - a proteção dos bens de cada um, pelo empenho comum e pela conjugação das forças de todos. Isso valeria mesmo antes de a lei civil fixar normas de apropriação privada, "pois a vida, o corpo e a liberdade teriam sido sempre bens próprios a cada um". Essa noção ampla de propriedade antecipa, obviamente, a noção lockiana.

Mas esse não é o único elemento grociano identificável, sem dificuldade, na obra de Locke. A concepção do mundo como patrimônio comum da humanidade, antes da apropriação privada de parcelas da natureza, ressurge no Primeiro tratado sobre o governo, escrito contra as teses de Filmer, e no capítulo 5 do Segundo tratado, uma longa e complexa exposição da teoria lockiana da propriedade. Mas a concepção da natureza como patrimônio originalmente comum vem de muito mais longe. É mais um elemento estoico do pensamento grociano e lockiano. 
Sêneca expõe essa noção numa das Cartas a Lucílio, a de número 90. Grotius prolonga a discussão, no entanto, explorando a diferença entre os bens passíveis e os não passíveis de apropriação. Os mares são incluídos nesta segunda categoria. Este é um elemento importante na discussão sobre os direitos das potências marítimas, no século XVII. Ele mesmo, como advogado da Companhia das Índias, recorreu a esse argumento ao justificar a captura de um barco português no Oriente.

Mas voltemos ao tema principal. Para avançar no debate sobre o direito da guerra e na guerra, Grotius precisa elucidar mais uma questão: a quem cabe o direito de guerrear? A guerra pode ser privada, mista ou pública, mas o foco da obra é o conflito entre Estados. Ora, só pode agir em nome do Estado o detentor da summa potestas, isto é, o detentor do poder soberano, seja qual for o ordenamento da sociedade política.

O poder civil é chamado soberano quando suas decisões não dependem de outra instância e não são anuláveis por outro agente. O sujeito desse poder é comum ou próprio, assim como "o sujeito comum da visão é o corpo e seu sujeito próprio, o olho" (Grotius, 2004, vol. I, p. 168 e p. 173). O sujeito comum da soberania é o Estado, ou um conjunto de Estados associados, e o sujeito próprio é a pessoa individual ou coletiva - um príncipe ou uma assembleia, por exemplo — investida de autoridade sobre o povo ou sobre os povos associados.

Grotius dispõe, a partir deste ponto, dos elementos necessários para entrar nos temas centrais de seu tratado. O Livro II discute as causas de conflito e as condições da guerra justa. As causas da guerra são tantas quantas são as causas dos processos. A luta começa quando falham as vias da justiça, isto é, quando não se pode apelar para um tribunal de jurisdição co- 
mum. Repetindo "a maior parte dos autores", Grotius menciona três causas de uma guerra justa: a defesa, a recuperação de uma propriedade e a punição. A essa enumeração ele adiciona um quarto motivo, a cobrança de algo devido.

Como princípio geral, o recurso à violência só é justificável diante de um perigo presente. A definição de perigo presente, admite Grotius, não é fácil: nas coisas morais, assim como nas coisas naturais, "não há ponto sem extensão". A precisão das noções, portanto, não pode ser geométrica. Diante de um agressor armado e aparentemente disposto a atacar, o uso da força pode ser a melhor solução. Mas ele insiste no cuidado. Se for possível evitar a resposta imediata, será esse o caminho recomendável. O tempo, argumenta Grotius, pode trazer a solução para o problema, tornando dispensáveis os males da guerra (Ibid., v. 1, p. 285). O direito internacional ainda valoriza a opinião grociana e mantém, como regra básica, a proibição do recurso à violência exceto como resposta a uma agressão. O conceito de agressão, como observa Cassese em seu belo livro International Law, permanece indefinido, ou definido de forma insuficiente. Esse fato, segundo ele, resulta de uma preferência dos principais atores internacionais, pois lhes concede certa flexibilidade na interpretação da norma. Em grande número de casos, no entanto, o ato de agressão é identificável sem maior dificuldade e a regra, portanto, é quase sempre aplicável sem dúvidas importantes.

As normas internacionais seriam diferentes, hoje, se tivesse prevalecido, entre os negociadores e juristas, a opinião kantiana exposta no final da Doutrina do Direito, primeiro componente da Metafísica dos costumes. Nesse texto, a guerra preventiva é apresentada, em termos bem hobbesianos, como a resposta naturalmente adequada ao fortalecimento de um Estado vizinho. 
No estado de natureza, segundo Kant, a busca do equilíbrio de poder é um direito essencial à segurança de cada um. Maquiavel provavelmente subscreveria esse ponto de vista. Mas os leitores com frequência deixam de lado esse ponto e valorizam as propostas da Paz Perpétua - embora mesmo essas propostas sejam apresentadas como um projeto de longuíssimo prazo, dependente da evolução política interna pelo menos um dos Estados mais importantes para a ordem internacional. A ideia comumente aceita de uma vertente grociano-kantiana, como oposta à hobbesiana, é portanto muito discutível.

Por outro lado, faz muito mais sentido, historicamente, contrapor à tradição hobbesiana (classificada como realista, por alguns) uma vertente formada por Vitória, Grotius, Locke e mais uma longa relação de autores modernos e contemporâneos. A ideia de uma sociedade formada por homens iguais e sujeitos a uma lei comum é parte dessa tradição. A lei natural, tal como entendida por aqueles clássicos, é muito mais que uma série de "teoremas da razão", expressão usada por Hobbes no final do capítulo XV do Leviatã. Na concepção de Vitória, Grotius e Locke, a lei natural é em tese tão aplicável quanto a lei positiva imposta por um juiz comum. Sem esse pressuposto, a noção de castigo não teria sentido fora da ordem legal do Estado. No entanto, a punição é parte do direito da guerra, tanto na obra vitoriana quanto na grociana. Locke pouco se ocupa do sistema internacional, mas a noção de pena é um complemento essencial de sua descrição do estado de natureza.

O miolo do problema consiste, no fundo, em decidir se a lei pode ser eficaz na ausência de um poder comum. Todos esses autores dão uma resposta positiva. Nenhum deles vive num mundo de fantasia e nenhum ignora as dificuldades e perigos de 
um sistema descentralizado. Mas todos admitem, teoricamente, a legalidade do julgamento e da punição mesmo quando não se pode recorrer a uma jurisdição instituída. O poder de punir, segundo Grotius, "nasce do crime do culpado" - no caso, de quem praticou a agressão ou de alguma forma lesou o direito de outrem.

De forma um tanto surpreendente, Grotius aproxima o direito penal do direito dos contratos e associa a punição à justiça comutativa, não à distributiva. Essa noção parece mais clara quando o direito de punir se infere do direito natural de defesa. A antiga liberdade natural, abandonada quando os homens erigem um poder comum, subsiste, no entanto, quando não há recurso possível a um tribunal, "como, por exemplo, no mar'. Neste sentido, a vingança é legítima, isto é, compatível com a lei natural, quando se destina a retribuir o crime e a impedir ou desencorajar sua repetição.

Mas a utilidade geral também é um dos fins da pena. Quem julga, condena e aplica a punição, nesse caso, age em vista não só do próprio interesse, mas também do interesse comum. Para Vitória, um dos objetivos da guerra e da punição dos violadores da lei natural e do direito das gentes é a proteção da sociedade universal.

Argumento semelhante aparece em Locke, no capítulo 2 do Segundo tratado. A impunidade do criminoso, segundo Grócio, pode encorajar a repetição do crime e é preciso agir para impedilo. Esse direito, "pertence naturalmente a cada um" (Grotius, 2004, v. 2, pp. 784-785). Essa noção é repetida em Locke: o juiz e aplicador do castigo, nesse caso, protege a humanidade e opera em seu nome.

Essas ideias podem parecer estranhas a muitos leitores con- 
temporâneos. Mas não causarão espanto àqueles familiarizados com a analogia entre o direito internacional e os sistemas legais "primitivos', descritos por Radcliffe Brown e mencionados por Kelsen (Kelsen, 2003, cap. VI, item A). Sob este aspecto, tem muito mais sentido associar o positivista Kelsen à tradição vitoriano-grociana do que à linhagem de Hobbes e dos demais grandes nomes do assim chamado realismo. E o jusnaturalismo? Neste momento, a pergunta soa um tanto acadêmica, no pior sentido. Um Grotius contemporâneo poderia simplesmente responder: dou o nome de lei natural não a um sistema de proposições metafísicas, mas ao conjunto das condições mínimas indispensáveis à vida coletiva. Não é esse, afinal, o "nódulo de bom senso do jusnaturalismo" apontado por Hart? (Hart, 1963)

O Livro III do Direito da guerra e da paz trata do lícito e do ilícito na condução do conflito: limites da violência, da astúcia e da mentira. Temas como o saque, o direito de presa, a segurança das populações civis, a responsabilidade dos súditos em relação aos crimes dos soberanos, o status das embaixadas e o valor das convenções durante as guerras estão incluídos na parte final do livro. O sentido das normas enunciadas pode ser sintetizado numa ideia simples e poderosa: o objetivo da guerra justa não pode ser senão o restabelecimento das condições necessárias à paz. O príncipe justo não pode esquecer esse ponto nem durante a guerra, nem no castigo dos culpados e na imposição de condições aos vencidos. Também este é um tema vitoriano. As advertências finais de Grócio e de Vitória foram esquecidas na Conferência de Versalhes. Foi uma das negligências mais custosas da história. 


\section{Referências bibliográficas}

CASSESE, A. International Law. Oxford: University Press, 2005.

GROTIUS, H. O direito da guerra e da paz. Ijuí: Editora Unijuí, 2004.

HART, I. A. The Concept of Law. Oxford: University Press, 1963.

HOBBES, T. Leviatã. Trad. Claudia Berliner. São Paulo: Martins Fontes, 2003.

KANT. I. Metafísica dos costumes. Trad. José Lamego. 2 ed. Lisboa: Calouste-Gulbenkian, 2011.

KELSEN, H. Teoria geral do direito e do Estado. Trad. Luís Carlos Borges. São Paulo: Martins Fontes, 2003.

KUNTZ, R. "República, direitos e ordem global". Lua Nova: Revista de Cultura e Política, São Paulo, n. 60, 2003, pp. 4555.

MESNARD, P. L'Essor de la philosophie politique au XVIe siècle. Paris: Boivin, 1936.

SCOTT, J. B. The Catholic Conception of International Law. Reedição, Clark. N. Jersey: The Lawbook Exchange, 2008.

. The Spanish Origin of International Law. Washington,

D.C.: Georgetown University of Foreign Service, 1928.

SÊNECA. Cartas a Lucílio. Trad. J. A. Segurado. 3 ed. Lisboa: Calouste-Gulbenkian, 2008.

SKINNER, Q. Fundações do pensamento político moderno. São Paulo: Companhia das Letras, 1996.

SUÁREZ, F. De Legibus ac Deo Legislatore/ Tratado de las leyes y de Dios legislador. Madrid: Instituto de Estúdios Políticos, 1967.

TUCK, R. Natural Right Theories. Cambridge: University 
Press, 1982.

VITÓRIA, F. "De la Potestad Civil". In: Reflectiones del Estado, de los indios y del derecho de la guerra. México: Editorial Porrúa, 1985.

. Political Writings. PAGDEN, A. (ed.). Cambridge University Press, 1991. 
